Dr. Rabia Sena ESER

Department of Turkısh Education, Firat University

Elazığ, Turkey

Assistant Prof. Dr. Hayrettin AYAZ ${ }^{2}$

Muş Alparslan University

Muş, Turkey
Original scientific paper

UDC: 371.315

DOI: $10.5937 /$ IstrPed2102639E

\title{
THE EFFECTS OF CREATIVE WRITING ACTIVITIES ON NARRATIVE TEXT WRITING SKILLS AND ADVANCED READING AWARENESS ${ }^{3}$
}

\begin{abstract}
The purpose of the present study was to determine the effect of creative writing exercises on narrative text writing skills and advanced reading awareness. To do that one of the mixed research designs, "exploratory sequential design" was used. The quantitative part of the study, in which a pretest post-test research design was used, consisted of $667^{\text {th }}$ grade students of a secondary school in the city center of Elazig. The participants were divided into two groups: The Experimental Group ( $\mathrm{N}=35)$, and the Control Group $(\mathrm{N}=31)$. In addition, 15 participants in the Experimental Group took part in the qualitative part. The data were obtained through the Narrative Text Writing Skills Rubric, Advanced Reading Awareness Scale, and Semi-Structured Interview Guide for Creative Writing Studies. The descriptive statistics, Independent Groups t-test, dependent groups t-test, Two-Way Variance Analysis for Mixed Measurements and Wilcoxon Signed Sequences Test were used in the analysis of quantitative data. The qualitative data were analyzed with the Content Analysis. The results of the quantitative data showed that the narrative text writing skills of the Experimental Group were statistically and significantly higher the Control Group. Furthermore, it was found that the advanced reading awareness levels of the Experimental Group increased more than the Control Group; however, this increase was not statistically significant. In addition, participans stated in the interviews that their narrative text writing skills improved, they gained courage and positive attitude towards writing, they formed a reading habit, they preferred books with events, their imagination developed, they gained the power to share and express. In sum, it was concluded that creative writing activities significantly improved narrative writing skills and improved to some extent advanced reading awaraness though a statistical significane was not found.
\end{abstract}

Keywords: Advanced Reading, Creative Writing, Narrative Text, Turkısh Education.

\footnotetext{
${ }_{1}^{1}$ r.sena_ak@hotmail.com

2hayrettinayaz@gmail.com

3 This article was produced from the author's doctoral thesis entitled "Yaratıcı yazma çalışmalarının öyküleyici metin yazma becerisine ve ileri okuma farkındalığına etkisi”.
} 


\section{Introduction}

Writing is an effective way to express oneself in society and to make these expressions permanent. For this reason, the individual needs to develop his / her writing skills in order to convey his / her imagination in writing and to create a written text that conforms to the writing conventions. The studies on students' writing revealed that they are not interested in writing compared to other language skills, and it was found that students were not motivated to write as desired, had serious anxiety about writing, and developed a negative attitude towards writing (Avci \& Iseri, 2014). Students' desire to write, motivation to write, and developing writing skills can only be possible by using various studies, methods and techniques for writing. The topics chosen in the writing activities, support, the steps to be applied in the writing process and the writing environment created by the instructor are important for making the writing activity effective.

The lack of creative thoughts, stereotypes, and subjects on which different perspectives cannot be developed lead students to be reluctant and constantly repeat the same sentences. Similarly, in traditional writing practices, the self-confidence of the student who cannot receive teacher support is decreased and the writing process ends when students see that they cannot express themselves (Temizkan, 2014). For this reason, it is necessary to provide a writing environment where students can easily present and organize their thoughts, freely consult ideas, get feedback on their mistakes by reviewing their writings, and reveal their creativity. The fact that writing activities emphasize skills such as planning, criticizing, developing, making decisions, and evaluating is directly related to creativity (Uzun, 2015), and one of the methods in which these skills can be improved is creative writing.

\subsection{Creative Writing and Narrative Text}

One of the methods that will develop creativity and personality and expand the imagination in all individuals is creative writing (Oral, 2014). In the creative writing process, which is one of the process-based writing techniques that takes students' writing process into account, there are situations such as going out of the ordinary without forcing normal values, producing different ideas from other people by using imagination, being original, writing fluently and with pleasure (Kucuk, 2007). Narrator's fiction effort underlies creative writing and the event, person, place, time, point of view and the narrator are the main elements of this world (Temizkan, 2014). The literary genres in which these elements exist are narrative texts, which is emphasized within the scope of this study. Many studies have revealed that teaching story elements improves students' reading comprehension skills and contributes to students' creative thinking and organizing thinking skills (Coskun, 2005).

Nowadays, it is important to reveal children's creativity in order to promote original products. Thus, the goal of creative writing activities is to develop the children's writing skills and to produce original products. Considering that comprehension and expression skills are developed with activities related to each other (Kaya, 2016), it can be said that reading skills are also developed with writing activities. Gunes (2017) stated that the development of writing skill is particularly directly related to reading and that developing writing skills depends on continuous reading, reviewing and discussing what is written and using various expression methods.

Reading skill refers to seeing, perceiving, comprehending and interpreting words, sentences or a text as a whole (Gunduz \& Simsek, 2011). Reading is also a process of establishing meaning, and an individual who performs the reading activity can achieve the purpose of reading by 
understanding the message the author wants to convey (Yilmaz, 2014). Reading activity is shaped by the combination of the contexts that exist in the text between at least two partie: the author and the reader (Ozbay \& Bahar, 2012). In this process, the reader interprets the text according to their personal characteristics, emotional state, and way of thinking, and thus, a number of reader types can be found in the literature. Critical reader, ideal reader, creative reader, implicit reader, informed reader, and plural reader are some of them. The reading activities performed by these types of readers differ from each other in various aspects. Within the scope of this study, the level of awareness of students regarding advanced reading will be discussed by focusing on the "advanced reading" performed by the "advanced reader".

\subsection{Advanced Reading}

As Ozbay and Bahar (2012) stated, advanced reader is a person who can use appropriate strategies before and during the reading process. Metacognition is one of these strategies. As a matter of fact, some researchers define readers who use metacognitive reading strategies as "advanced readers" (Kana, 2014). While evaluating the individual's awareness of advanced reading, the use of metacognitive strategies was primarily considered in the reading process. Metacognition plays an important role in many areas of reading comprehension, writing, criticizing, persuasion, interpretation, problem solving, social cognition, self-control and selfteaching (Flavell, 1979). Metacognition, in the context of reading, includes the reader's use of previous knowledge, determining the purpose of reading, predicting what the author wants to tell, evaluating the accuracy of these predictions, and establishing a link between his own life and what is described in the text in accordance with the principle of intertextuality (Hacker, 2004 as cited in Babacan, 2012).

Considering that creative writing and advanced reading process consist of similar processes such as pre-skill (planning / drafting), during skill (reading / writing), post-skill (evaluation / correction) and that various strategies should be used to make the skill effective in these processes, the concept of metacognition is emphasized in both skills. Being able to express oneself effectively through writing and having a good level of reading comprehension requires the individual to be able to control their own learning and to benefit from various strategies. In this case, metacognitive skill play a significan role.

The concept of metacognition is defined as the effective monitoring of cognitive processes, their regulation as a result of monitoring, and their harmonization with other cognitive processes (Flavell, 1979). Cognitive awareness improves the quality of skills and helps the writer to write better and the reader to read better. The correlation between writing and reading skills suggests that a good writer can also be a good reader. As a matter of fact, when it is considered that writing is an interactive activity depending on the exchange of ideas, it is inevitable that every individual who is interested in writing and wants to improve writing is also required to develop reading skill (Ipsiroglu, 2006).

Reading and writing requires self-discovery and critical thinking skills (Wang, 2012), and these skills include common processes and strategies (Parodi, 2007). Considering that language skills are based on a cognitive process and metacognitive features such as monitoring and correction are needed in both writing and reading skills, it can be said that a planned process is required for the development of writing and reading, and metacognitive skills are important in both processes. Writing skill is an important process that allows the person to use high-level cognitive skills such as analysis, synthesis and evaluation, and in this process, it is necessary to organize thoughts, conduct research on a topic, and establish a link between the previous and 
new information (Tiryaki \& Demir, 2016). As a matter of fact, it is known that there is little evidence that writers who are weak in the physical and mechanical aspects of writing tend to convey ideas directly and consider stages such as planning and revision in their writings (McCutchen, 1996). This situation is similar to the fact that advanced readers follow the planning and review stages, while the poor readers have a lack of awareness as to these stages.

\subsection{The Present Study}

Although the process-based writing model is adopted in the Turkish Lesson Curriculum (2018), there are difficulties in applying this model in schools and as a result product-based approaches are still applied. This situation has been confirmed by studies in the literature which has revealed that teachers do not have sufficient knowledge about process-based approaches and creative writing techniques, therefore they cannot practice process-based writing and creative writing adequately in classrooms (Akkaya, 2014; Asikcan \& Pilten, 2016; Guney, 2016; Maltepe, 2006; Temizkan and Yalcinkaya, 2013). Due to the inability to implement process-oriented writing activities, students' writing skills do not develop at the desired level and the writing activities they do in order to produce a product do not motivate students to write. The implementation of writing activities, which were thought to be uncreative, stereotypical and boring for students, was the starting point for this research. As a matter of fact, it is thought that creative writing activities are important in order to open a door to the imaginary world of the child, to enable them to express themselves comfortably and to have fun while writing. In the creative writing process in which creative thinking is emphasized, the type of text in which the student will realize creative thinking and expressing this through writing in the most appropriate way is narrative texts. Many studies have revealed that teaching story elements improves students' reading comprehension skills and contributes to students' creative thinking and organizing their thoughts (Coskun, 2005).

Reading skill provides to understand the types of written texts. Reading, which is a communication process, takes place between two parties, the writer and the reader, and in this way, reading skill predicts writing and writing skill predicts reading skill (Ozbay \& Bahar, 2012). The idea that students use their imaginations more richly in narrative texts, that writing and reading skills, which are based on a metacognitive process, affect each other in direct proportion, and that factors such as awareness and attitude are also a part of the acquired skill shed light on the research.

\section{The Signifacence of the Study}

The present study is important to reveal how creative writing practices affect both the narrative text writing skill, where creativity can be used at a high level, and the advanced reading awareness level. To the best of the reserchers, no study has been conducted on this issue. In addition, it is thought that the research will contribute to the literature in terms of examining the general effect of creative writing studies on two skills at the same time.

\section{The Aim of This Study}

The aim of this study is to determine the effect of creative writing activities on students' narrative text writing skills and advanced reading awareness. In line with this general purpose, the following questions were sought:

1. Is there a significant difference in favor of the experimental group between the achievement scores of narrative text writing skills of the experimental group and the control group students? 
2. Is there a significant difference in favor of the experimental group between the advanced reading awareness achievement scores of the experimental group and the control group students?

3. What are the experimental group students' opinions about the application process consisting of creative writing activities?

4. What are the experimental group students' opinions about the positive / negative contributions of the application process?

5. Are there any activities that the experimental group students enjoyed and had difficulties during the application process? If so, what are the reasons for enjoying these activities or having difficulties?

6. Did the creative writing activities affect the reading desire and attitudes of the experimental group students? If so, how was this effect?

7. Did the creative writing activities affect the experimental group students' desire and attitude to write narrative texts? If so, how was this effect?

8. Is there a situation that the experimental group students deem lacking or want to make suggestions for the application process?

\section{Method}

\subsection{Research Design}

The descriptive sequential design, one of the mixed research methods in which qualitative and quantitative research strategies are used together, was used. In the descriptive sequential design, the researcher first conducts the quantitative study and analyze the results, and then reconstruct them to explain in more detail with qualitative research (Creswell, 2017). The purpose of using this pattern in studies is to use the qualitative stage to explain the relationships and trends within quantitative data (Creswell, Plano Clark, Gutmann, \& Hanson 2003). In the quantitative dimension of the study, a quasi-experimental model with "pre-testpost-test control group" was used. In addition, interview technique was used in qualitative research dimension.

\subsection{Participants}

The convenience sampling technique was used in choosing the study group. The selection criteria were based on the researcher's own judgement, and the institution where it was thought that the study would be conducted more regularly and with higher quality (seen as voluntary / close / easily accessible). Prior to the study, required official permissions were obtained from the Elazig Provincial Directorate of National Education. The study group consisted of 66 students studying in the 7th grade of a secondary school in Elazig. In order to determine the experimental and control groups, students' pretest scores (experimental group $\bar{x}: .9736$, control group $\bar{x}: 1.1030$ ), first term lecture grades (experimental group $\bar{x}: 78.59$, control group $\bar{x}: 74.35$ ) and class sizes (experimental group 35, control group 31) were compared. There was no significant difference between both the Turkish course grade point averages and the narrative text writing pre-test scores of the students in the two departments where the study was conducted. For this reason, the experimental and control groups were determined randomly. The semi-structured interview consisting of seven open-ended questions was conducted with 15 participants in the experimental group. In studies using interviews to be applied after experimental studies, intead of the size or smallness of the number of study groups whether the group meets the amount of information needed is checked (Turnuklu, 2000). Therefore, qualitative data were limited to data obtained from 15 participants. 


\subsection{Data Collection Tools}

Narrative Text Writing Skills Rubric: A rubric prepared by the researchers was used to evaluate the experimental and control group students' performances regarding narrative text writing skills before and after the application. Scoring key, which has content validity (1.00) and consists of 26 items, consists of 2 items in the "Format" dimension, 13 items in the "Language and Expression" dimension, and 11 items in the "Narrative Text Elements" dimension. The narrative texts obtained within the scope of the study were graded and scored according to three items in the form: o (Insufficient), 1 (Improved) and 2 (Sufficient).

Advanced Reading Awareness Scale: An awareness scale prepared by the researchers was used to determine the advanced reading levels of the participants. The scale consists of three dimensions as "before reading (planning), reading order (process monitoring) and after reading (evaluation)" and 21 items (Cronbach's Alpha "reliability coefficient" .87).

Semi-Structured Interview Guide for Creative Writing Studies: Interview, which is one of the qualitative data collection methods, is necessary in order to see how people express their environment or behaviors and emotions we cannot observe (Merriam, 2015). It is thought that open-ended questions prepared to reveal the thoughts that need to be discovered will be a way to enable the student to think independently. The questions in the guide, which was prepared in line with the feedback from experts, are as follows:

1. What are your thoughts on the creative writing process?

2. Do you think that the creative writing studies made have a positive / negative contribution to you? Why is that?

3. Did you enjoy the creative writing activities done during this period? Which or which one? Why is that?

4. Have you ever had difficulty with the creative writing activities carried out during this period? Which or which one? Why is that?

5. Do you think there is any change in your desire and attitude towards reading as a result of creative writing activities? How?

6. As a result of your creative writing activities, do you think there is any change in your desire and attitude to write narrative texts? How?

7. What are your suggestions about the creative writing activities we did during the 8 weeks or the process?

\subsection{Data Collection Process}

The data collection process, including pre-test and post-test, was planned as two hours a week and ten weeks in total. The Advanced Reading Awareness Scale and the narrative texts the students wrote on the topic they chose among the given topic were used as pre-test and posttest. A separate two-hours lesson plan was prepared for each week in an eight-week period. In this lesson plan, students were required to brainstorm for creative writing, define oneself, use techniques such as analogy, associate the given words, write with materials such as story cubes and salt shakers. During these creative writing activities, various reading texts such as "Sinagrit Baba (S. Faik Abasiyanik)" were read to provide an example, and students were able to read and correct the texts they wrote. In this way, writing and reading skills were combined within the scope of creative writing activities. In addition, creative writing activities were carried out mostly individually and sometimes in groups, depending on the type of activity. 
In the control group, the writing activities in the Turkish Teaching Program were carried out without any intervention. The post-tests were applied in the tenth week of the application. After obtaining the quantitative data, in order to support the study with qualitative data, interviews were made with the students. The participation to the interviews was on voluntary basis. The lessons in the control group and the applications in the experimental group were carried out by the same teacher in order to conduct the experimental in a successful way. Before the implementation, detailed information about the purpose of the study and how it would be carried out was given to the teacher and lesson plans were shared with the teacher.

\subsection{Analysis of Data}

The quantitative data were analyzed using SPSS 23, which is a data analysis package program for social sciences. After determining whether the data was normally distributed or not, Levene test was used for the homogeneity of the group scores. According to the obtained results, independent groups t-test, dependent groups t-test and two-way analysis of variance for mixed measurements were used as the data were normally distributed. In cases where a significant difference was determined, the effect size value was checked.

The qualitative data were analyzed through the opinions of 15 participants. Face to face interviews were conducted. In order to ensure that the interviews were reliable, the interviews were recorded with a tape recorder and the obtained data were transcribed into a word processor. The content analysis method was used for the data analysis. The content analysis aims at reaching the concepts and relationships that can explain the collected data, gathering similar data within the framework of certain concepts and themes, and organizing and interpreting them in a way that the reader can understand (Yildirim \& Simsek, 2013). In order to ensure coder reliability, the data were encoded at different times by the researcher, and in this way, it was tried to provide "coder reliability (89\%)" (Miles \& Huberman, 2016). In addition, while directly reporting the opinions of the participant, the participants were coded as "K1E, K2 K, K3E ..." in order to indicate who the interviewed student was. Each participant was anonymized in the interview process. The acronyms of the participant, the number, and gender were used in the anonymization process, respectively. The first letter in the coding is the acronym of the participant, the second is the number of the participant, and the third is the gender of the participant.

\section{Findings}

\subsection{Quantitative Findings}

\section{Findings Regarding Narrative Text Writing Skill}

It was examined whether there was a significant difference between the achievement scores of the narrative text writing skills of the students in the experimental group (EG) and control groups (CG). In order to see whether the posttest scores of the groups showed normal distribution, the skewness coefficient / standard error (SC / se) and the kurtosis coefficient / standard error (BK / sh) were tested with the Kolmogorov-Smirnov normality test. In the calculation of narrative text writing skill achievement scores, the normal distribution of the data was defined as "EG (SC / se $=.115, \mathrm{BK} / \mathrm{se}=-1.037)$ and CG $(\mathrm{SC} / \mathrm{se}=.097, \mathrm{BK} / \mathrm{se}=.811)$, EG (K =. 069, $\mathrm{p}=.200)$ and CG $(\mathrm{K}=.171, \mathrm{p}=.022)$ ". Therefore, it was decided to use independent groups $\mathrm{t}$-test. Another condition that must be met in order to perform the independent samples t-test is that the variances regarding the distribution of measurements in the group are equal (Can, 
2017). When the pre-test and post-test scores of the experimental and control group students were examined, it was seen that the group variances were homogeneous $[p=.240>.05]$.

The findings related to the Research Question 1 are given in Table 1.

Table 1. Analysis Results Regarding Narrative Text Writing Skills Achievement Scores

\begin{tabular}{|c|c|c|c|c|c|c|c|c|}
\hline & Group & $\mathrm{n}$ & $\bar{X}$ & Ss & $\mathrm{sd}$ & $t$ & $\mathrm{P}$ & $\eta 2$ \\
\hline \multirow{2}{*}{ Access } & EG & 35 & .2887 & .18475 & 64 & 6.978 & $.000^{* *}$ & .43 \\
\hline & CG & 31 & -.0447 & .20330 & & & & \\
\hline
\end{tabular}

As shown in Table 1, the independent groups t-test results demonstrated that that there was a significant difference between the achievement scores of the experimental and control group students in narrative writing skills $(t=6.978, p=.000<.05)$. It was observed that the creative writing activities carried out for eight weeks positively affected the narrative text writing skills of the students in the experimental group at a very high level $(\eta 2=.43)$.

The narrative text writing skill was dealt in three dimensions: form, language-expression and narrative text elements. In order to see the effect of creative writing activities on each dimension, Wilcoxon Signed Ranks Test and dependent groups t test were used. As a result, it was seen that the writing skills of the experimental group students developed in all three dimensions after the experimental. The effect dimension of this development showed that the development of "form $(r=-.54)$, language-expression $(\eta 2=.53)$ and narrative text elements ( $\eta 2$ $=.61) "$ was very high in all three dimensions.

\section{Findings Regarding Advanced Reading Awareness}

Two-factor analysis of variance was used for mixed measurements to compare the pre-test and post-test scores of students' advanced reading awareness. In this context, the conditions required for the analysis were checked first. The first of the required conditions of two-factor analysis of variance for mixed measures is that the scores of the groups (pre-test and post-test scores) depending on the dependent variable show normal distribution in each group (Can, 2017: 248). The skewness coefficient / standard error (SC / sh) and kurtosis coefficient / standard error (BK / sh) of the groups were examined to see whether the pre-test-post-test scores showed normal distribution. According to this test, EG students' pre-test (SC / se $=-.449$, BK / se $=-.735)$, CG students' pre-test (SC / se $=.106, \mathrm{BK} / \mathrm{se}=-.658)$; posttest of the EG students (SC / $\mathrm{se}=-.391, \mathrm{BK} / \mathrm{se}=-1.249)$ and the post-test of CG students $(\mathrm{SC} / \mathrm{se}=-1.437, \mathrm{BK} / \mathrm{se}=1.400)$ were found to be normally distributed. The second required condition is the equal variances regarding the distribution of measurements in the group (Can, 2017, p.248). In this study, the homogeneity of the group variances was controlled by the Levene test and it was found that the group variances were homogeneous $[p=.177>.05]$. Another condition is that there should be no significant difference between group covariances. Accordingly, for pair combinations of measurement groups, there should be no significant difference between group covariances; in other words, the p value should be greater than .05 (Can, 2017, p. 248). Equality of covariance matrices was checked by Box's $M$ test. As a result of the analysis, it was determined that the equality of covariance matrices was achieved [(Box's $M=1.006, F=.324, p=.808>.05)$ ]. The analysis was carried out after it was seen that all the necessary conditions were met to apply the two-factor analysis of variance for mixed measurements.

Table 2 presents descriptive statistics regarding the experimental and control group and the scores they obtained from the scale. 
Table 2. Descriptive Statistics Results Related to Advanced Reading Awareness of Students

\begin{tabular}{lllllll}
\hline & \multicolumn{2}{l}{ Pre-Test } & \multicolumn{4}{c}{ Post-Test } \\
\hline Group & $\mathrm{n}$ & $\bar{X}$ & Ss & $\mathrm{n}$ & $\bar{X}$ & Ss \\
\hline Experimental & 35 & 3.5293 & .54914 & 35 & 3.7782 & .63918 \\
\hline Control & 31 & 3.5668 & .59353 & 31 & 3.5853 & .56023 \\
\hline
\end{tabular}

Table 2 shows that the pre-test average score of the experimental group was 3.52, and it increased to 3.77 after the application. On the other hand, the CG students' scores were 3.56 before the application, it is seen that this value was 3.58 after the application.

In order to test whether creative writing activities had a significant effect on students' test scores, two-way analysis of variance was performed for mixed measurements. Analysis results are given in Table 3.

Table 3. Two-Way Analysis of Variance Results for Mixed Measures

\begin{tabular}{|c|c|c|c|c|c|}
\hline Source of Variance & Sum of Squares & sd & Average of Squares & $\mathbf{F}$ & $\mathrm{p}$ \\
\hline \multicolumn{6}{|l|}{ Between Groups } \\
\hline Group (E/C) & .199 & 1 & .199 & .377 & .542 \\
\hline Error & 33.732 & 64 & .527 & & \\
\hline \multicolumn{6}{|l|}{ In Groups } \\
\hline $\begin{array}{l}\text { Measurement (Pre- } \\
\text { Test/Post-Test) }\end{array}$ & .588 & 1 & .588 & 3.618 & .062 \\
\hline Group * Measurement & .437 & 1 & .437 & 2.690 & .106 \\
\hline Error & 10.396 & 64 & .162 & & \\
\hline
\end{tabular}

In the analysis in Table 3, group students belong to (experimental and control) refers to between the groups, and the measurement of scores (pre-test and post-test) the within-group factor. The between the groups results showed that there was no significant difference between the post-test and pre-test total scores of the experimental group and the control group $[F=.377, p=.542>.01)]$. However, intergroup analysis alone is not sufficient and thus, the changes seen in the groups from pre-test to post-test should also be taken into account. When students in both the experimental and control group were treated as one group, it was found that there was no significant difference between the students' post-test scores and pretest scores. $[F=3.618, p=.62>.01)]$.

One of the aims of the study was to determine the effect of two different applications (creative writing studies and current writing education based on Turkish Teaching Program) on improving students' advanced reading awareness. For this reason, both analyzes were not sufficient as it was important to investigate the joint effect of group and measurement factors in order to reveal the source of change in all students. Table 3 shows that the group (EG and CG) and measurement (pre-test-post-test) factors together had a significant effect on further reading awareness $[F=2.690, p=.106>.01)]$. 


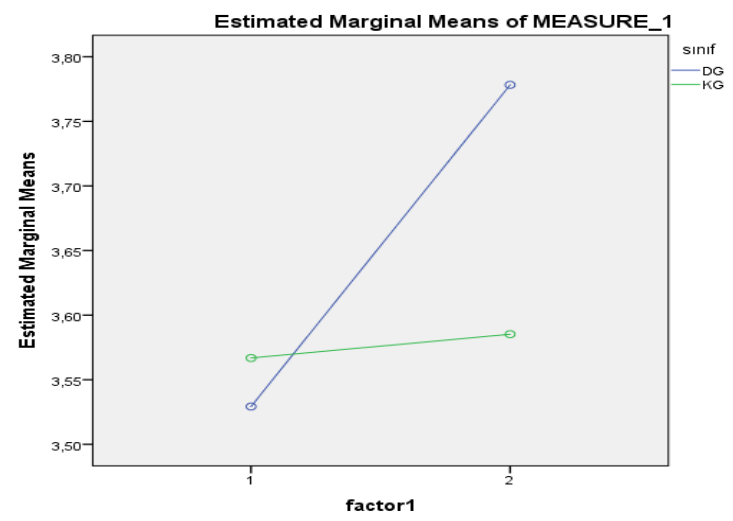

Figure 1. The Effect of Creative Writing Activities on Forward Reading Awareness Level

The pre-test and post-test scores that the experimental and control groups obtained from the scale are shown in Figure 1. Although pretest scores were close to each other and that there was no significant relationship between them, the posttest scores of the groups were found to be different as a result of the independent samples t-test. Posttest scores of the experimental group relatively increased compared to the control group. This increase may be interpreted as that creative writing activities are more effective in improving students' advanced reading awareness compared to the Turkish Language Teaching Program. However, this increase was not significant enough to reveal a statistical difference.

Advanced reading awareness level was addressed in three dimensions: pre-reading (planning), during reading (process monitoring) and post-reading (evaluation). In order to see how creative writing activities, affect each dimension, Wilcoxon Signed Ranks Test and dependent groups $t$ test were analyzed. As a result of the dependent samples $t$ test, it was determined that the awareness of the experimental group students only after reading (evaluation) developed in a very high dimension $(\eta 2=.25)$ after the application.

\subsection{Qualitative Findings}

Analyzed qualitative findings are classified under 6 themes: "writing process", "student achievements", "activities enjoyed and forced (reasons)", "desire and attitude to read", "desire and attitude to write narrative text", "suggestion".

\section{Findings Regarding the Writing Process Theme}

Interview questions aimed at finding out opinions of the participants regarding to the implementation process. Accordingly, the participants stated in the interviews that the writing process gave them motivation, it was an educational-instructive process as well as a necessary process for them, and that they had fun in this process. The codes related to the writing process theme are given in Table 4. 
Table 4. Findings Regarding the Writing Process Theme

\begin{tabular}{|c|c|c|c|c|c|}
\hline \multirow{9}{*}{ 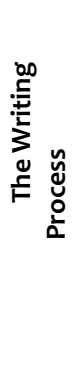 } & \multirow{3}{*}{$\begin{array}{l}\text { Codes } \\
\text { Motivation }\end{array}$} & & \multirow{2}{*}{$\frac{f}{7}$} & \multirow{2}{*}{$\frac{n}{6}$} & \multirow{2}{*}{$\begin{array}{l}\text { Participants } \\
\mathrm{K} 1 \mathrm{E}, \mathrm{K} 2 \mathrm{~K}, \mathrm{~K} 9 \mathrm{~K}, \mathrm{~K} 10 \mathrm{~K}, \mathrm{~K} 11 \mathrm{E}, \mathrm{K} 13 \mathrm{~K}\end{array}$} \\
\hline & & Interest & & & \\
\hline & & Effectiveness & 3 & 2 & K7K, K9K \\
\hline & \multirow{6}{*}{$\begin{array}{l}\text { Educational- } \\
\text { Tutorial }\end{array}$} & Perspective & 2 & 2 & $\mathrm{~K}_{5} \mathrm{E}, \mathrm{K} 11 \mathrm{E}$ \\
\hline & & Chance to practice & 2 & 2 & K5E, K10K \\
\hline & & Instructive & 7 & 5 & $\mathrm{~K} 2 \mathrm{~K}, \mathrm{~K} 3 \mathrm{~K}, \mathrm{~K} 4 \mathrm{E}, \mathrm{K} 12 \mathrm{E}, \mathrm{K} 14 \mathrm{~K}$ \\
\hline & & Change & 4 & 4 & $\mathrm{~K} 3 \mathrm{~K}, \mathrm{~K} 4 \mathrm{E}, \mathrm{K} 6 \mathrm{E}, \mathrm{K} 8 \mathrm{~K}$ \\
\hline & & Funny & 16 & 13 & $\begin{array}{l}\mathrm{K} 1 \mathrm{E}, \mathrm{K} 2 \mathrm{~K}, \mathrm{~K} 3 \mathrm{~K}, \mathrm{~K} 4 \mathrm{E}, \mathrm{K}_{5} \mathrm{E}, \mathrm{K} 6 \mathrm{E}, \mathrm{K} 7 \mathrm{~K}, \mathrm{~K} 8 \mathrm{~K}, \\
\mathrm{~K} 10 \mathrm{~K}, \mathrm{~K} 12 \mathrm{E}, \mathrm{K} 13 \mathrm{~K}, \mathrm{~K} 14 \mathrm{~K}, \mathrm{~K} 15 \mathrm{~K}\end{array}$ \\
\hline & & Necessary & 1 & 1 & $\mathrm{~K} 14 \mathrm{~K}$ \\
\hline
\end{tabular}

Some of the participants' views on the writing process are as follows:

“... It was very good, there were nice changes in our article, we gained more information. It was fun compared to the other lessons... (K8K)"

"... I was mostly writing composition, I didn't have much interest and skills in other genres. But when we held activities for stories and fairy tales, my perspective towards the tale and story changed. I was interested. We used our imagination more than the previous lessons. We used to not do such applications ... (K11K)"

\section{Findings Regarding the Theme of Student Outcomes}

In the interviews, the participants were asked to elaborate on the contribution of the 8-week creative writing activities. None of the participants indicated a negative contribution and stated that this process conributed them positively.

Table 5. Findings Regarding the Theme of Student Outcomes

\begin{tabular}{|c|c|c|c|c|}
\hline Codes & & $f$ & $\mathbf{n}$ & Participants \\
\hline \multirow{4}{*}{$\begin{array}{l}\text { Text } \\
\text { Awareness }\end{array}$} & Vocabulary & 2 & 1 & K5E \\
\hline & Punctuation and spelling rules & 14 & 10 & $\begin{array}{l}\mathrm{K} 1 \mathrm{E}, \mathrm{K} 2 \mathrm{~K}, \mathrm{~K} 3 \mathrm{~K}, \mathrm{~K} 6 \mathrm{E}, \mathrm{K} 7 \mathrm{~K}, \\
\mathrm{~K} 8 \mathrm{~K}, \mathrm{~K} 11 \mathrm{~K}, \mathrm{~K} 12 \mathrm{E}, \mathrm{K} 14 \mathrm{~K}, \mathrm{~K} 15 \mathrm{~K}\end{array}$ \\
\hline & The stages of the text & 8 & 6 & $\begin{array}{l}\text { K4E, K5E, K10K, K11K,K12E, } \\
\text { K15 }\end{array}$ \\
\hline & Text type & 5 & 4 & $\mathrm{~K} 4 \mathrm{E}, \mathrm{K} 7 \mathrm{~K}, \mathrm{~K} 11 \mathrm{~K}, \mathrm{~K} 15 \mathrm{~K}$ \\
\hline \multirow{7}{*}{$\begin{array}{l}\text { Transfer to } \\
\text { Life }\end{array}$} & Application scope & 3 & 3 & $\mathrm{~K} 2 \mathrm{~K}, \mathrm{~K} 9 \mathrm{~K}, \mathrm{~K} 14 \mathrm{~K}$ \\
\hline & Sharing & 2 & 2 & K9K, K13K \\
\hline & Power of expression & 4 & 3 & $\mathrm{~K} 4 \mathrm{E}, \mathrm{K} 10 \mathrm{~K}, \mathrm{~K} 12 \mathrm{E}$ \\
\hline & Interest in the lesson & 3 & 3 & K6E, K9K, K10K \\
\hline & Permanence & 2 & 1 & $\mathrm{~K} 13 \mathrm{~K}$ \\
\hline & Imagination-Creativity & 15 & 12 & $\begin{array}{l}\mathrm{K} 1 \mathrm{E}, \mathrm{K} 2 \mathrm{~K}, \mathrm{~K} 3 \mathrm{~K}, \mathrm{~K} 4 \mathrm{E}, \mathrm{K} 6 \mathrm{E}, \mathrm{K} 7 \mathrm{~K} \text {, } \\
\mathrm{K} 9 \mathrm{~K}, \mathrm{~K} 10 \mathrm{~K}, \mathrm{~K} 11 \mathrm{~K}, \mathrm{~K} 12 \mathrm{E}, \mathrm{K} 13 \mathrm{~K}, \\
\mathrm{~K}_{15} \mathrm{~K}\end{array}$ \\
\hline & Read & 9 & 4 & $\mathrm{~K}_{1} \mathrm{E}, \mathrm{K}_{2} \mathrm{~K}, \mathrm{~K}_{3} \mathrm{~K}, \mathrm{~K} 10 \mathrm{~K}$ \\
\hline
\end{tabular}

As seen in Table 5, there are 2 focus codes and 11 codes with regard to student achievement theme. Some of the participants' views on these codes are as follows: 
“... They made positive contributions. Our way of thinking developed our imagination. We learned something about spelling and punctuation. We can correct the text after writing it. Our thoughtful development ways have improved. Our ability to interpret has improved. Our sense of writing has improved. We realized that we can write not only in one genre, but also in other text types... (K15K)"

"... It was positive and I learned the spelling of words most of all. I learned to transcribe a poem, for example, now I love reading a book. I think my interpretation and imagination improved... (P3E)"

"... Now I pay more attention to my writing. Every time I feel like someone is going to check it, I write accordingly. As I read and speak, I realize that I follow the rules of writing. While talking, for example, I stop and breathe as if there was a comma and continue like that... (K14K)"

\section{Findings Regarding the Theme of Enjoyable and Difficult Activities (Reasons)}

The participants' opinions about the activities they enjoyed and had difficulties while practicing and the reasons for enjoying these activities were included under this theme. Participant views are presented in Table 6 and Table 7.

Table 6. Findings Regarding the Activities Enjoyed (Reasons) Theme

\begin{tabular}{|c|c|c|c|c|c|}
\hline \multirow{19}{*}{ 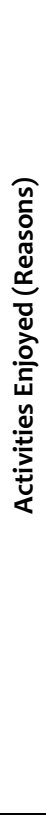 } & Codes & & $f$ & $\mathbf{n}$ & Participants \\
\hline & \multirow{8}{*}{ Activities } & Perspective & 1 & 1 & K6E \\
\hline & & Story cubes & 20 & 14 & $\begin{array}{l}\text { K1E, K2K, K3K,K4E, K5E, K6E, K7K, } \\
\text { K9K, K10K, K11K, K12E, K13K, K14K, } \\
\text { K15K }\end{array}$ \\
\hline & & Brainstorming to the image & 4 & 4 & K7K, K10K, K13K, K15K \\
\hline & & Animate the characters! & 1 & 1 & $\mathrm{~K} 12 \mathrm{E}$ \\
\hline & & Who do you think you are? & 7 & 5 & $\mathrm{~K}_{1} \mathrm{E}, \mathrm{K} 4 \mathrm{E}, \mathrm{K}_{5} \mathrm{E}, \mathrm{K} 9 \mathrm{~K}, \mathrm{~K}_{13} \mathrm{~K}$ \\
\hline & & Complementing the text & 5 & 5 & $\mathrm{~K} 11 \mathrm{~K}$ \\
\hline & & Convert poem to story & 2 & 2 & $\mathrm{~K} 8 \mathrm{~K}, \mathrm{~K} 15 \mathrm{~K}$ \\
\hline & & Salt shaker (idea generator) & 19 & 12 & $\begin{array}{l}\text { K2K, K3 K, K4E, K5E, K6E, K8K, K9K, } \\
\text { K10K, K11K, K12E, K13K, K15K }\end{array}$ \\
\hline & \multirow{10}{*}{ Reasons } & Reconciling thought & 5 & 5 & K4E, K5E, K9K, K11K, K15K \\
\hline & & Interest in handicraft & 1 & 1 & $\mathrm{~K} 13 \mathrm{~K}$ \\
\hline & & Empathy & 1 & 1 & K6E \\
\hline & & Different & 3 & 3 & K4E, K5E, K10K \\
\hline & & Team work & 5 & 3 & $\mathrm{~K}_{2} \mathrm{~K}, \mathrm{~K}_{3} \mathrm{~K}, \mathrm{~K}_{13} \mathrm{~K}$ \\
\hline & & $\begin{array}{l}\text { Unlimited imagination- } \\
\text { creativity }\end{array}$ & 10 & 8 & $\begin{array}{l}\text { K4E, K9K, K10K, K11K, K12E, K13K, } \\
\text { K14K, K15K }\end{array}$ \\
\hline & & To express yourself & 6 & 6 & K1E, K4E, K9K, K10K, K12E, K15K \\
\hline & & Knowing yourself & 1 & 1 & K13K \\
\hline & & Awareness of the text type & 1 & 1 & $\mathrm{~K} 6 \mathrm{E}$ \\
\hline & & Game & 2 & 2 & K12E, K14K \\
\hline
\end{tabular}

Table 7. Findings Regarding Difficult Activities (Causes) Theme

\begin{tabular}{|c|c|c|c|c|c|}
\hline \multirow{8}{*}{ 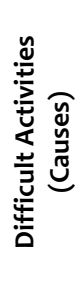 } & \multirow{2}{*}{\multicolumn{2}{|c|}{ Codes }} & \multirow{2}{*}{$\begin{array}{l}f \\
1\end{array}$} & \multirow{2}{*}{$\begin{array}{l}\mathbf{n} \\
1 \\
\end{array}$} & \multirow{2}{*}{$\begin{array}{l}\text { Participants } \\
\mathrm{K} 11 \mathrm{~K}\end{array}$} \\
\hline & & & & & \\
\hline & \multirow{6}{*}{ Activities } & Gap-filling & 1 & 1 & $\mathrm{~K} 6 \mathrm{E}$ \\
\hline & & Sentence expansion & 2 & 2 & K13K, K15K \\
\hline & & Story cubes & 1 & 1 & $\mathrm{~K}_{3} \mathrm{~K}$ \\
\hline & & Animate the characters! & 1 & 1 & $\mathrm{~K} 4 \mathrm{E}$ \\
\hline & & Who do you think you are? & 3 & 3 & K1E, K7K, K14K \\
\hline & & Convert poem to story & 3 & 3 & K3K, K6E, K13K \\
\hline
\end{tabular}




\begin{tabular}{lllll}
\hline & Salt shaker (idea generator) & 1 & 1 & K8K \\
\cline { 2 - 6 } & Inexperience & 5 & 5 & K4E, K5E, K6E, K12E, K15K \\
\cline { 2 - 5 } Reasons & Thinking reconciliation & 2 & 2 & K3K, K8K \\
\cline { 2 - 5 } & Empathy & 1 & 1 & $\mathrm{~K} 11 \mathrm{~K}$ \\
\cline { 2 - 5 } & Inadequate expression & 1 & 1 & $\mathrm{~K} 1 \mathrm{E}$ \\
\cline { 2 - 5 } & Knowing yourself & 3 & 2 & $\mathrm{~K} 7 \mathrm{~K}, \mathrm{~K} 14 \mathrm{~K}$ \\
\hline
\end{tabular}

As can be seen in Table 6 and Table 7, 10 codes were identified for the reasons of the activities enjoyed while 5 codes were determined for the difficult activities. Some of the opinions of the participants about the activities they enjoyed and had difficulty are as follows:

"... The activities I enjoyed the most were salt shakers and story cubes. I also loved creating a hero (animate characters!) And creating stories. Because we have transferred ourselves to paper. We expanded our imagination. The fact that it is a play drew our attention more and I am waiting for the writing lesson every week because it will be a game... (K12E)

"... I enjoyed the salt shaker, turning it into a story from poetry. I had a hard time combining events in the salt shaker... (K8K)"

"... The gap-filling activity in the first week challenged me. I thought that it would be difficult to turn the poem into a story, but I understood that there was actually a story in the poem... (P6E)"

"... I had a little difficulty in the phobias hobbies activity (Who do you think you are?). I could not express myself fully, but now it is not like that, I can express myself better... (K1E)"

\section{Findings Regarding the Theme of Reading Desire and Attitude}

Participant opinions were taken to determine how creative writing activities affect reading desire and attitude. 6 codes were determined in relation to this theme: interest, book volume, understanding power, perspective, attention and regular reading. The codes mentioned are given in Table 8.

Table 8. Findings Regarding the Theme of Reading Desire and Attitude

\begin{tabular}{|c|c|c|c|c|}
\hline \multirow{7}{*}{ 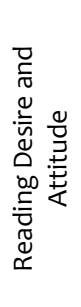 } & Codes & $f$ & $\mathrm{n}$ & Participants \\
\hline & Area of interest & 6 & 6 & $\mathrm{~K}_{1} \mathrm{E}, \mathrm{K} 2 \mathrm{~K}, \mathrm{~K}_{3} \mathrm{~K}, \mathrm{~K} 6 \mathrm{E}, \mathrm{K}_{9} \mathrm{~K}, \mathrm{~K}_{10 \mathrm{~K}}$ \\
\hline & Book volume & 3 & 3 & $\mathrm{~K} 4 \mathrm{E}, \mathrm{K} 11 \mathrm{~K}, \mathrm{~K} 14 \mathrm{~K}$ \\
\hline & Power of understanding & 1 & 1 & $\mathrm{~K} 11 \mathrm{~K}$ \\
\hline & Perspective & 1 & 1 & $\mathrm{~K} 13 \mathrm{~K}$ \\
\hline & Attention & 2 & 2 & K5E, K14K \\
\hline & Regular reading & 1 & 1 & $\mathrm{~K} 12 \mathrm{E}$ \\
\hline
\end{tabular}

There were participants who stated that they were inclined towards practices, they observed a change in reading desire and attitude, that they were more careful while reading, that their desire to read increased but they were not able to explain this increase, and that they used to read a lot of books, but after the practice, they focused on writing since it was more enjoyable. Some of the participants' views on the theme of reading desire and attitude are as follows:

"... I already liked to read. I no longer forcefully read a book. I already had a request, but your attitude has changed. After these events, I learned to look at the events in detail... (K13K)" 
“... I read by paying attention to spelling and punctuation rules. I don't think it affected my request much... (K5E)"

"... I started to be more selective about book subjects. I used to read a lot of books, but now we can say that reading has taken the second place because writing gives me more pleasure... (K2K)"

\section{Findings Regarding the Theme of Writing Narrative Text Desire and Attitude}

In order to see the effect of creative writing activities on participants 'desire and attitude to write narrative texts, participants' opinions were obtained. It was found that the participants expressed their opinions under 6 codes. These codes are given in Table 9.

Table 9. Findings Regarding the Theme of Desire and Attitude to Write Narrative Text

\begin{tabular}{|c|c|c|c|c|}
\hline \multirow{7}{*}{ 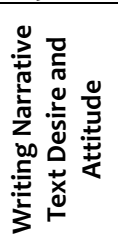 } & Codes & $f$ & n & Participants \\
\hline & The ability to express & 1 & 1 & $\mathrm{~K} 5 \mathrm{E}$ \\
\hline & Fluent writing & 2 & 2 & $\mathrm{~K} 1 \mathrm{E}, \mathrm{K} 4 \mathrm{E}$ \\
\hline & Awareness & 2 & 2 & K11K, K14K \\
\hline & Different types of text & 4 & 3 & $\mathrm{~K} 2 \mathrm{~K}, \mathrm{~K} 11 \mathrm{~K}, \mathrm{~K} 15 \mathrm{~K}$ \\
\hline & Imagination - Creativity & 7 & 5 & $\mathrm{~K} 4 \mathrm{E}, \mathrm{K} 7 \mathrm{~K}, \mathrm{~K} 10 \mathrm{~K}, \mathrm{~K} 12 \mathrm{E}, \mathrm{K} 13 \mathrm{~K}$ \\
\hline & Courage to share & 2 & 2 & $\mathrm{~K} 5 \mathrm{E}, \mathrm{K} 9 \mathrm{~K}$ \\
\hline
\end{tabular}

All participants expressed a positive opinion about the desire and attitude to write narrative texts after their creative writing practices, and they explained what kind of changes occurred in their desire and attitude to write narrative text after the application. However, although three participants $(\mathrm{K} 3 \mathrm{~K}, \mathrm{~K} 6 \mathrm{E}, \mathrm{K} 8 \mathrm{~K})$ stated that there was a positive change in their desire to write narrative texts, they did not give detailed information about this change. Some of the participant views are as follows:

"... I started to like to write narrative text. It used to be unnecessary and difficult to write narrative text. I don't think so anymore... (K2K)"

"... I used to struggle a lot with character selection. I can find it more easily now. This increased my desire and I started to write more fluently... (K4E) "

"... My desire to write a story has increased so much, I still continue the story in the salt shaker activity ... (K6E)"

\section{Findings Regarding the Suggestion Theme}

Participants were asked to state the deficiencies, if any, in the implementation process and to make suggestions regarding the process. The suggestions of the participants for the implementation process are given in Table 10.

Table 10. Findings Regarding the Suggestion Theme

\begin{tabular}{|c|c|c|c|c|}
\hline \multirow{4}{*}{ 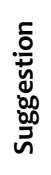 } & Codes & $f$ & n & Participants \\
\hline & Team work & 1 & 1 & $\mathrm{~K} 4 \mathrm{E}$ \\
\hline & Material & 1 & 1 & $\mathrm{~K} 4 \mathrm{E}$ \\
\hline & Time & 8 & 7 & $\mathrm{~K}_{1} \mathrm{E}, \mathrm{K} 2 \mathrm{~K}, \mathrm{~K}_{3} \mathrm{~K}, \mathrm{~K}_{12} \mathrm{E}, \mathrm{K} 13 \mathrm{~K}, \mathrm{~K} 14 \mathrm{~K}, \mathrm{~K} 15 \mathrm{~K}$ \\
\hline
\end{tabular}

While 8 of the participants made suggestions for the implementation process, 7 of them $(\mathrm{K} 5 \mathrm{E}$, $\mathrm{K} 6 \mathrm{E}, \mathrm{K} 7 \mathrm{~K}, \mathrm{~K} 8 \mathrm{~K}, \mathrm{~K} 9 \mathrm{~K}, \mathrm{~K} 10 \mathrm{~K}, \mathrm{~K} 11 \mathrm{~K})$ stated that there was no deficieny in the application process. Some of the participant views are as follows: 
"... All were in place and beautiful. I think you do things more according to our weaknesses. I think everything was in place. I think we use the time efficiently... (K11K)"

"... It would be nice if it were two days a week; One day we would play games and the other day we would write texts. We would have more time to think. I wish we had more time... (K12K)"

\section{Conclusion, Discussion and Suggestions}

\section{Narrative Text Writing}

The results demonstrated that including creative writing practices in 7th grade Turkish lessons positively affected the narrative text writing skills of students. Studies in the literature shows that that creative writing practices are effective in improving students' writing skills, and writing studies have a positive impact on writing skill, writing attitude, lesson attitude, writing anxiety, speaking skills, creative writing skills. It can be seen in the literature that there are a large number of studies investigating the general effect of creative writing practices on writing skills (Ak, 2011; Alar, 2018; Beydemir, 2010; Dorlay, 2018; Duran, 2010; Korkmaz, 2015; Majid, Kay, \& Soh, 2003 Tok \& Kandemir, 2015; Tonyali, 2010; Yildirim, 2018). However, there are few studies examining the specific effect of creative writing practices on text types / narrative text writing. These studies have found that creative writing practices developed narrative text writing skills (Kutno, 1993; Rubin, 2000; Conroy, Marchand \& Webster, 2009; Temizkan, 2011), and private ownership technique developed story writing skills together with creative writing practices (Peker, 2015). Furthermore, there are also studies (Demir, 2012) that have reached conclusions that creative writing skills can be developed.

It was observed the students in the experimental group wrote their writings more carefully, legibly and developed their ability to create paragraphs in the text after the creative writing practices. By improving the skills of "choosing the right title for the text, producing meaningful sentences, expressing thoughts with correct words, finishing sentences in place, ensuring consistency and subject integrity in the text, using ways to improve thought and phrases, enrich the text and apply spelling-punctuation rules", they made a significant progress in "language expression" dimension. It was observed that the experimental group students improved significantly within the scope of "narrative text elements". In this dimension, there are plot, theme, main idea, narrator point of view, sequence-knot-solution sections, reaction to solution, characters, time and space. Creative writing activities significantly increase verbal creativity (Baskok, 2012), provide a positive development within the scope of grammar rules (Alar, 2018; Melanlioglu \& Atalay, 2016), increase their success in Turkish lessons at an acceptable level (Kuvanc, 2008). It is also known that it enables students to express themselves more comfortably (Duran, 2010; Kilic, 2018), to decide on more creative and appropriate title for the text (Ozdemir \& Cevik, 2018), to use more varied vocabulary (Mollaoglu, 2002) and to ensure fluency of words and thoughts (Yuksel, 2016). Furthermore, students use more original characters in their creative writing products, write interesting features in describing characters, events and places and create an original hero based on imagination (Beydemir, 2010).

The qualitative data obtained during the research process verify the quantitative data. Students in the experimental group stated that the creative writing process was a fun and efficient process that increased the interest in the lesson, gave perspective to text types and thoughts, taught writing in different genres, improved other language skills, provided expressiveness and environment, and instills self-confidence. Emotions such as interest, curiosity and excitement 
also increased students' enthusiasm for the lesson. Participants stated that they had the chance to apply the theoretical knowledge they had learned thus far on topics such as spellingpunctuation in this process. This situation shows that the information taught in the existing educational process is not applied in practice, and the writing activities are not effective enough to provide it.

Among the creative writing activities, the participants stated that they mostly enjoyed story cubes and idea generator (salt shaker) works. The common feature of these two activities is that they are based on material usage. It was noticed that the activities using materials in the classroom were more enthusiastically and eagerly welcomed by the students. It was determined that the students were generally interested in activities that were different, had a playful feature, and allows for creativity. Participants stated that they had difficulties in some activities (Who do you think you are? Turn the poem into a story.)

Participants' realization that they were not aware of themselves and their inability to establish a connection between text types caused difficulties in these activities. It can be said that increasing creative writing activities and making them do it continuously will provide students with experience in this field and improve their expression skills. After the application, the participants stated that they could write more creative texts, expressed themselves more comfortably in writing, wrote stories, did not hesitate to share what they wrote, chose story elements more easily, and developed a positive attitude towards writing. In general, the participants emphasized that creative writing practices were effective in developing positive attitudes and increasing desire for narrative text writing. The free idea environment offered to the students and the reinforcement of creative thoughts led the students to express ideas and develop the courage to share the text they wrote, even if it was funny. It was observed that students who could not produce ideas about narrative text elements such as characters were able to generate ideas more comfortably after the application, and even if the concepts did not seem related, they could combine them within the framework of an event. On the other hand, it was determined that students who did not like to write narrative texts gained awareness of the text type and developed a positive attitude towards these texts.

In the content of the criticism, most of the participants stated that the time should be longer and some participants stated taht there could be more group work. Considering that the writing skill is a skill that spans the process, requires feedback and requires a thinking process, it is natural for the participants to find the practice time of two hours a week inadequate. As a matter of fact, making evaluations at the end of the creative writing process and giving feedback to the written texts are effective in making students write better and love to write, but sharing and evaluating each student's article is a very time consuming situation (Ozdemir \& Cevik, 2018). As a result, it was concluded that the qualitative findings obtained support the quantitative findings.

\section{Advanced Reading Awareness}

Pre-test and post-test scores showed that there was no significant difference between the experimental and control group students' advanced reading awareness levels. However, it was observed that the post-test scores of both groups were different and the experimental group had relatively higher scores in the scale. This difference, which was not large enough to reveal a statistical difference, can be seen in Figure 1 . 
A brief literature analysis showed that there was a linear relationship between writing and reading, using reading and metacognitive reading strategies, and creativity and reading. Feldman (2012) analyzed the relationship between students' writing activity and reading scores, and found that the time spent on writing together with various variables affected their reading scores in a statistically significant way. Ataman (2006), Cikla (2002) and Saxby (1997) stated that works such as fiction and imagination contributed to creativity.

In the present study, it was seen that creative writing activities affected the advanced reading awareness level of students only enough to reveal a significant difference in the assessment dimension. Considering that creative writing skills increase metacognitive skills and writing skills increase improve reading skills, the lack of improvement in all dimensions can be explained with the fact that students did not fill the scales reliably. As a matter of fact, when the students' opinions were consulted after the application, the students stated that their reading skills were positively affected after the creative writing activities.

Studies in the literature show that the written expressions of individuals who have not acquired a reading habit are negatively affected (Dalkilic-Fer, 2017). In this case, based on this close relationship between writing and reading, it can be said that creative writing studies should be supported with reading studies and reading studies should be supported by creative writing activities.

Whether the participants observed a change in their reading desire and attitude after the application was also questioned in this study. Most of the participants stated that they experienced a positive change in their reading desire and attitude. The statements of the participants showed that creative writing activities gave participants the pleasure of reading books, the power to make sense of events, the ability to interpret events with imagination, the courage to read voluminous and event-based books, the ability to read books by paying attention to spelling and punctuation, and the habit of regular reading every night. The findings of the qualitative data may be interpreted as that creative writing studies contribute to the individual in terms of interpretation power, interpretation skills, and selection of the book to be read, and it is expected that the application will affect the level of advanced reading awareness in a way that will reveal a significant difference. However, the findings of the quantitative data showed the relationship between creative writing activities and advanced reading awareness level was not significant. This suggests that the awareness scales may be affected by the prevailing conditions of individuals. As a matter of fact, studies in the literature show that there is a directly proportional relationship between writing and reading skills (Choi, Moon, Paek, \& Kang, 2018; Graber, 1989; Maya, 1979; Stotsky, 1983). For example, Kasap (2019) showed that creative reading and creative writing practices in primary school Turkish lessons had positive effects on increasing students' creative reading, reading comprehension, writing and creative writing achievements. Similarly, Maya (1979) emphasized that writing skill is important in the development of reading, thinking, speaking and listening skills, and stated that creative writing activities should be done in order to improve reading skill. Furthermore, according to Oguz (2009), prospective teachers did not read and like to read books due primarily to their insufficient written expression skills. Studies in the literature also show that writing and reading skills improve each other.

When the qualitative and quantitative findings of the study are considered together, it can be said that creative writing activities are more effective than current teaching practices in improving students' narrative text writing skills. In this sense, the qualitative findings support the quantitative findings in the present study. It was determined that the advanced reading 
awareness of the students increased at the end of the creative writing process, but this difference was not statistically significant. This finding, also investigated with qualitative data, was interpreted as that the experimental group students' advanced reading awareness and reading interest increased within the scope of reading skill, but students could not reflect this on the scales. In general, it can be said that creative writing studies based on a metacognitive process improved the narrative text writing skill to a high degree, and the advanced reading awareness in which metacognitive strategies were used, to a some extent.

Based on the current research, the following recommendations can be made:

- In this study, the effect of creative writing practices on narrative text writing skill was examined. The effect of creative writing practices on other text types and structures can also be examined.

- The present study consisted of carried 7 th grade students, future studies can be carried out with different study groups such as different grade levels or teacher candidates.

- Studies can be conducted to examine the level of awareness of creative writing practices on language skills other than reading.

- Retention test could not be performed due to reasons such as the second term of the application and the summer break. In order to test whether the development in students' narrative text writing skills is permanent or not, a retention test can be used in future studies.

- In the present study, quasi-experimental design supported by qualitative data was adopted. Studies using different methods on the same subject can be conducted.

- While examining the effect of creative writing activities on reading and writing text types, quantitative data can be collected to see how motivational factors such as selfefficacy perception and attitude are also affected.

- Research can also be conducted to see the effects of creative writing activities on writing, listening or speaking skills based on metacognitive skills.

- Contribution can be made to the field by carrying out various studies in order to reveal the relationship between creative writing activities and reading skills.

\section{References:}

Ak, E. (2011). Yaratici Yazma Tekniklerinin Ilkogretim 5. Sınıf Ogrencilerinin Turkce Dersindeki Yazili Anlatım Becerileri Uzerindeki Etkisi. Doctoral Thesis, Dokuz Eylul University Institute of Educational Sciences, Izmir.

Akkaya, N. (2014). Sinif Ogretmenlerinin Yaratici Yazma Surecine Iliskin Goruslerinin Degerlendirilmesi. Kuram ve Uygulamada Egitim Bilimleri, 14(4), 1487-1504.

Asikcan, M. \& Pilten, G. (2016). Sinif Ogretmenlerinin Yazili Anlatim Calismalarinin Surec Temelli Yazma Modeli Odakli Degerlendirilmesi. Turkish Studies, 11(3), 255-276.

Alar, S. (2018). Clustering (Kumeleme) Yaratici Yazma Yonteminin Turkce Ogrenen Yabanci Ogrencilerin Yazma Becerisi Uzerine Etkisi. Yuksek Lisans Tezi, Mersin Universitesi Egitim Bilimleri Enstitusu, Mersin.

Ataman, M. (2006). Yaratici Drama Surecinde Yaratici Yazma. Yaratici Drama Dergisi, 1(1), 75-87.

Avci, A. S. \& Iseri, K. (2014). Yaratici Yazma Etkinliklerinin Sekizinci Sinif Ogrencilerinin Yazma Egilimleri ve Yazma Kaygılarına Etkisi. International Journal of Language Academy, 2(4), 152-169. 
Babacan, T. (2012). Sinif Ogretmeni Adaylarinin Ustbilissel Okuma Stratejileri ile Coklu Zeka Alanlari Arasindaki lliskinin Incelenmesi. Yayimlanmamis Yuksek Lisans Tezi, Cumhuriyet Universitesi, Egitim Bilimleri Enstitusu, Sivas.

Baskok, B. (2012). Ilkogretim Yedinci Sinif Ogrencilerine Uygulanan Yaratici Yazma Calismalarinin, Ogrencilerin Yaraticiliklarina ve Turkce Dersine Olan Tutumlarina Etkisinin Incelenmesi. Yuksek Lisans Tezi, Akdeniz Universitesi Sosyal Bilimler Enstitusu, Antalya.

Beydemir, A. (2010). Ilkogretim 5. Sinıf Turkce Dersinde Yaratici Yazma Yaklasiminin Yazmaya Yonelik Tutumlara, Yaratici Yazma ve Yazma Erisisine Etkisi. Yuksek Lisans Tezi, Pamukkale Universitesi Egitim Bilimleri Enstitusu, Denizli.

Can, A. (2017). SPSS ile Bilimsel Arastırma Surecinde Nicel Veri Analizi. Ankara, Pegem Akademi.

Choi, J., Moon, Y., Paek, J. K., \& Kang, Y. (2018). Examining the Relationship Between Reading and Writing of Advanced Korean EFL Learners, 34(1), 91-116.

Conroy, M, Marchand, T. \& Webster, M. (2009). Motivating Primary Students to Write Using Writer's Workshop. Online Submission, Master of Arts Action Research Project, Saint Xavier University.

Coskun, E. (2005). Ilkogretim Ogrencilerinin Oykuleyici Anlatımlarında Bagdasiklik, Tutarlilik ve Metin Elementleri. Doktora Tezi, Gazi Universitesi Egitim Bilimleri Enstitusu, Ankara.

Creswell, J. W. (2017). Arastirma Deseni: Nitel, Nicel ve Karma Yontem Yaklasimlari. (Cev. Ed: S. B. Demir). Istanbul, Egiten Kitap.

Creswell, J. W., Plano Clark, V. L., Gutmann, M. L., \& Hanson, W. E. (2003). Advanced Mixed Methods Research Designs. In: A. Tashakkori \& C. Teddlie (Eds.), Handbook on Mixed Methodsi the Behavioral and Social Sciences. Thousand Oaks, CA: Sage Publications (pp. 209-240).

CIkla, S. (2002). Romanda Kurmaca ve Gerceklik. Hece Turk Roman Ozel Sayisi, Sayi: 65/66/67, $111-129$.

Dalkilic Fer, T. (2017). Ilkogretim Ogrencilerinin Yaratici Yazi Calismalarinin Surec Icerisindeki Gelisimlerinin Incelenmesi ve Degerlendirilmesi. Yuksek Lisans Tezi, Bahcesehir Universitesi Egitim Bilimleri Enstitusu, Istanbul.

Demir, T. (2012). Turkce Egitiminde Yaratici Yazma Becerisini Gelistirme ve Kucurek Oyku. Mustafa Kemal Universitesi Sosyal Bilimler Enstitusu Dergisi, 9(19), 343-357.

Dorlay, O. (2018). 5E Ogrenme Modeline Uygun Yaratici Yazma Etkinliklerinin Ortaokul Ogrencilerinin Yazma Becerisi Uzerine Etkisi. Yuksek Lisans Tezi, Kirikkale Universitesi Sosyal Bilimler Enstitusu, Kirikkale.

Duran, S. (2010). Yaratici Yazma Yaklasiminin Yazili Anlatim Becerisinin Gelisimine Etkisi. Yuksek Lisans Tezi, Trakya Universitesi, Sosyal Bilimler Enstitusu, Edirne.

Feldman, D. (2012). The Relationship of Writing and Writing Instruction with Standardized Reading Scores for Secondary Students. Ohio Reading Teacher, 42(1).

Flavell, J. H. (1979). Metacognition and Cognitive Monitoring: A New Area of CognitiveDevelopmental Inquiry. American Psychologist, 34(10), 906.

Graber-Wilson, G. (1989). The Extent of The Relationship Between Reading and Writing Achievement Among International Students Enrolled in a University Freshman Composition Course. Doctoral dissertation, Oregon State University.

Gunduz, O. \& Simsek, T. (2013). Uygulamali Okuma Egitimi El Kitabi. Ankara, Grafiker Yayinlari.

Gunes, F. (2017). Turkce Ogretimi: Yaklasimlar ve Modeller. Ankara, Pegem Akademi.

Guney, N. (2016). Ogretmenlerin Yazma Egitimine Yonelik Dusunceleri. Uluslararasi Turkce Edebiyat Kultur Egitim Dergisi, 5 (2), 970-985.

Ilkogretim Turkce Dersi (1-8. Siniflar) Ogretim Programı (2018). Turkce Dersi (1-8. Siniflar) Ogretim Programi. Ankara, MEB.

Ipsiroglu, Z. (2006). Yaratici Yazma Calismalarinda Yazinsal Metinlerin Islevi Yaratici Yazma. Ankara, Morpa Kultur Yayinlari. 
Kana, F. (2014). Ortaokul Ogrencilerinin Okuma Stillerinin Incelenmesi. Journal of International Social Research, 8(40).

Kasap, D. (2019). Yaratici Okuma-Yaratici Yazma Calismalarinin Yaratici Okuma, Okudugunu Anlama, Yazma ve Yaratici Yazma Erisisine Etkisi. Doktora Tezi, Pamukkale Universitesi Egitim Bilimleri Enstitusu, Denizli.

Kaya, B. (2016). Ust bilissel Beceri Odakli Yazma Sureclerinin Dorduncu Sinif Ogrencilerinin Hikaye Yazma Becerisine Etkisi. Yuksek Lisans Tezi, Gazi Universitesi Egitim Bilimleri Enstitusu, Ankara.

Kilic, U. (2018). 9. Sinif Ogrencilerine Uygulanan Drama Yontemine Dayali Yaratici Yazma Calismalarinin Yazma Tutumuna Etkisinin Incelenmesi. Yuksek Lisans Tezi, Marmara Universitesi Egitim Bilimleri Enstitusu, Istanbul.

Korkmaz, G. (2015). Yaratici Yazma Yonteminin 6. Sinif Ogrencilerinin Yazma Oz Yeterlik Algilarina, Yazmaya Iliskin Tutumlarına ve Yazma Becerisi Akademik Basarılarina Etkisi. Yuksek Lisans Tezi, Gaziantep Universitesi Egitim Bilimleri Enstitusu, Gaziantep.

Kutno, S. P. (1993). Creative Writing in the Urban Middle School: Writing Imagined Narratives to Think About College. University at Buffalo, Buffalo.

Kuvanc, E. B. (2008). Yaratici Yazma Tekniklerinin Ogrencilerin Turkce Dersine Iliskin Tutumlarına ve Turkce Dersindeki Basarılarına Etkisi. Yuksek Lisans Tezi, Dokuz Eylul Universitesi, Egitim Bilimleri Enstitusu, Izmir.

Kucuk, S. (2007). Yazulu Anlatim ve Yaraticilik. Samsun, Ondokuz Mayis Universitesi Yayinlari.

Majid, D., Kay, T., \& Soh, C. (2003). Enhancing Children's Creativity: An Exploratory Study on Using the Internet and Scamper as Creative Writing Tools. The Korean Journal of Thinking \& Problem Solving, 13 (2), 67-81.

Maltepe, S. (2006). Yaraici Yazma Yaklasimi Acisindan Turkce Derslerindeki Yazma Sureclerinin ve Urunlerinin Degerlendirilmesi. Doktora Tezi, Ankara Universitesi, Sosyal Bilimler Enstitusu, Ankara.

Maya, A. Y. (1979). Write to Read: Improving Reading Through Creative Writing. The Reading Teacher, 32(7), 813-817.

McCutchen, D. (1996). A Capacity Theory of Writing: Working Memory in Composition. Educational Psychology Review, 8(3), 299-325.

Melanlioglu, D. \& Atalay, T. D. (2016). Yabanci Dil Olarak Turkce Ogrenenlerin Yazma Oz Yeterlikleri Uzerinde Yaratici Yazma Uygulamalarinin Etkisi. Turkiye Sosyal Arastirmalar Dergisi, 20(3), 697-721.

Merriam, S. B. (2015). Nitel Arastırma-Desen ve Uygulama icin Bir Rehber (Cev.: S. Turan). Ankara, Nobel Yayinlari.

Miles, M. B. \& Huberman, A. M. (2016). Genisletilmis Bir Kaynak Kitap: Nitel Veri Analizi. (Cev. Edt. : Altun, S. A. \& Ersoy, A.). Ankara: Pegem Akademi.

Mollaoglu, A. (2002). Yaratici Yazma Ilkelerinin ve Yontemlerinin Almanca Dil Dersinde Uygulanmasi ve Ogrencilerin Yazma Becerisinin Gelistirilmesi. Doktora tezi, Hacettepe Universitesi Sosyal Bilimler Enstitusu, Ankara.

Oguz, A. (2009). Ogretmen Adaylarinin Sozlu ve Yazili Anlatim Becerilerine lliskin Oz Yeterlik Algilari. Electronic Journal of Social Sciences, 8(30).

Oral, G. (2014). Yine Yazi Yaziyoruz. Ankara, Pegem Akademi Yayincilik.

Ozbay, M. \& Bahar, M. A. (2012). Ileri Okur ve Ustbilis Egitimi. Uluslararasi Turkce Edebiyat Kultur Egitim (TEKE) Dergisi, 1(1).

Ozdemir, S. \& Cevik, A. (2018). The Effect of Creative Writing Studies on Attitudes towards Writing and the Creative Writing Success. Journal of the Faculty of Education, 19(2), 141153.

Parodi, G. (2007). Reading-Writing Connections: Discourse-Oriented Research. Reading and Writing, 20 (3), 225-250. 
Peker, S. (2015). Yazili Anlatim Becerilerinin Gelistirilmesinde Yaratici Drama Tekniklerinden Ozel Mulkiyet Tekniginin Yaratici Yazma Yaklasimi ile Karsilastirilmasi. Yuksek Lisans Tezi, Ankara Universitesi Egitim Bilimleri Enstitusu, Ankara.

Rubin, D. (2000). Teaching Elementary Language Arts: A Balanced Approach. Boston: A Pearson Education Company.

Saxby, H. M. (1997). Books in the Life of a Child: BriEGes to Literature and Learning. South Melbourne: Macmillan Education Australia.

Stotsky, S. (1983). Research on Reading/Writing Relationships: A Synthesis and Suggested Directions. Language Arts, 6o(5), 627-642.

Temizkan, M. (2011). Yaratici Yazma Etkinliklerinin Oyku Yazma Becerisi Uzerindeki Etkisi. Kuram ve Uygulamada Egitim Bilimleri Dergisi (Educational Sciences: Theory \& Practice), 11(2), 919-940.

Temizkan, M. (2014). Yaratici Yazma Ssreci. Ankara: Pegem Akademi.

Temizkan, M. \& Yalcinkaya, M. (2013). Ilkogretim 6. 7. 8. Sinif Turkce Ogretmenlerinin Yaratici Yazma Etkinliklerini Uygulama Durumlari. Ziya Gokalp Egitim Fakultesi Dergisi, 20, 7091.

Tiryaki, E \& Demir, A. (2016). Turkce Ogretmeni Adaylarinin Yazma Becerisine Yonelik Metaforik Algilari. Mustafa Kemal Universitesi Sosyal Bilimler Enstitusu Dergisi, 13 (33) , 18-27.

Tok, S. \& Kandemir, A. (2015). Effects of Creative Writing Activities on Students' Achievement in Writing, Writing Dispositions and Attitude to English. Procedia-Social and Behavioral Sciences, 174, 1635-1642.

Tonyali, E. (2010). Yaratici Yazma Uygulamalarinin Ilkogretim Altinci Sinif Ogrencilerinin Yazma Becerilerine Etkisi. Yuksek Lisans Tezi, Abant Izzet Baysal Universitesi Sosyal Bilimler Enstitusu, Bolu.

Turnuklu, A. (2000). Egitimbilim Arastirmalarinda Etkin Olarak Kullanilabilecek Nitel Bir Arastirma Teknigi: Gorusme. Kuram ve Uygulamada Egitim Yonetimi, Sayi: 24, Guz 2000, ss. 543-559.

Uzun, A. (2015). Yaratici Yazma Etkinliklerinin Cinli Ogrencilerin Yabanci Dil Olarak Turkce Yazma Becerilerine Etkisi. Yuksek Lisans Tezi, Ataturk Universitesi Egitim Bilimleri Enstitusu. Erzurum.

Wang, A. Y. (2012). Exploring The Relationship of Creative Thinking to Reading and Writing. Thinking Skills and Creativity, 7 (1), 38-47.

Yildirim, A. \& Simsek, H. (2013). Sosyal Bilimlerde Nitel Arastırma Yontemleri. Ankara, SeSCin Yayincilik.

Yildirim, G. (2018). Yaratici Yazma Etkinliklerinin Turkce Ogretmen Adaylarının Yazma Becerisine Etkisi. Yuksek Lisans Tezi, Canakkale Onsekiz Mart Universitesi Egitim Bilimleri Enstitusu, Canakkale.

Yilmaz, M. (2014). Okuma Egitimi. Yilmaz, M. (Ed.) Yeni Gelismeler Isiginda Turkce Ogretimi. Ankara, Pegem Akademi Yayinlari, s. 77-106.

Yuksel, T. (2016). Ortaokul 5. Sinif Turkce Derslerinde Uygulanan Yaratici Yazma Etkinliklerinin Ogrencilerin Yazmaya Yonelik Tutumlarına ve Sozel Yaraticiliklarina Etkisinin Incelenmesi. Yuksek lisans tezi, Akdeniz Universitesi Egitim Bilimleri Enstitusu, Antalya.

\section{Biographical notes:}

Dr. Rabia Sena ESER, completed her undergraduate degree in 2013, her master's degree in 2015, and her doctorate degree in 2020 at Firat University, Department of Turkish Education. The researcher has been working as a research assistant in the Turkish Education Department of Firat University since 2014. Her research interest consists of creative writing, writing skills, 
reading habits, information technologies and language skills, Turkish textbooks, children's literature.

Ass. Prof. Dr. Hayrettin AYAZ, completed his primary, secondary and high school education in Elazig. He graduated from Istanbul University, Faculty of Letters, Department of Turkish Language and Literature (1980). He completed his master's and doctorate degrees at Firat University. He worked as a Turkish Language Instructor and as an academic member at the Faculty of Education, Department of Turkish Education in Firat University between 1983-2019. He is still working as an academic member in Muş Alparslan University, Faculty of Communication. 